Copyright (C) 2016 by Academic Publishing House Researcher

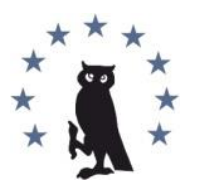

Published in the Russian Federation

European Researcher

Has been issued since 2010.

ISSN 2219-8229

E-ISSN 2224-0136

Vol. 105, Is. 4, pp. 208-215, 2016

DOI: 10.13187/er.2016.105.208

www.erjournal.ru

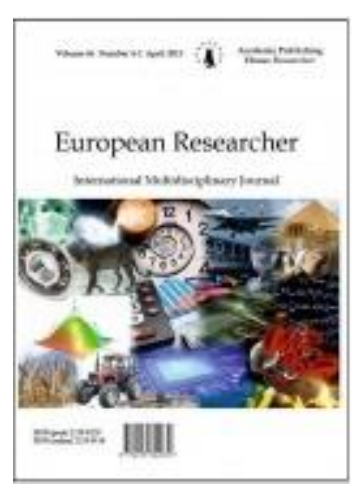

Pedagogical Sciences

Педагогические науки

UDC 37

\title{
Attitudes of Primary School Pupils towards Physical and Sport Education
}

\author{
${ }^{1}$ Pavol Bartík \\ 2 Ján Kubiš
}

\author{
1-2 Matej Bel University, Slovakia \\ Tajovského 40, 97401 Banská Bystrica \\ ${ }^{1}$ Dr. (Pedagogic Sciences), PhD, Professor \\ E-mail: pavol.bartik@umb.sk \\ ${ }^{2}$ Mgr. (Pedagogic Sciences) \\ E-mail: janesumb@gmail.com
}

\begin{abstract}
One of the most important roles of spare time physical education is the formation of a positive attitude towards sports activities and sports among pupils. The formation of a positive attitude can play an important role in the matter of a child's healthy lifestyle. Therefore the authors of this article decided to find out what kind of a relationship and an attitude the pupils of primary schools take towards physical education and sports activities in the Detva and Zvolen regions. The authors of this article present the attitudes towards physical education and movement as well as sports activities of $8^{\text {th }}$ grade primary school pupils in the Detva and Zvolen regions as well as to their frequency. The authors discuss which activities among extracurricular or spare-time activities are the most interesting for pupils. According to the results presented in the charts, it is clear that pupils take a positive attitude towards physical education and sports activities. Sports games belong among the most favourite interest groups.
\end{abstract}

Keywords: attitudes, physical education, sports activities, spare time activities.

\section{Introduction}

Movement and sports activities can affect the physical development of an individual to a large extent; both increase their efficiency and strengthen their health. Movement activity creates a positive antipole against the present-day sedentary lifestyle among children and youth who sit a great deal of the day not only in school, but also afternoons and evenings during preparation for the next day of school, when watching TV, while communicating on social networks and being on the computer. In this age movement activity is being largely sought out and at the same time it is one of the most significant needs of a child. There is a decrease in movement activities and movement performance (Frömel, Novosad and Svozil, 1999; Pavlík, 1999; Šíma et al., 1998; 
Sigmund et al., 2003; Chow and Fung, 2005). To set the accurate motivation of youth towards movement activity we need to know the structure of their movement interests. Attitudes are factors affecting our perception and our interpretation of the perceived as well as which information we relate to one another and which not. Attitudes save time, improve our orientation in the social environment, give us confidence, knowing what we are looking for and what we want to avoid.

According to Görner (1998), extracurricular education has its irreplaceable place in the upbringing process of children and youth. From the point of view of educational work efficiency, extracurricular education e.g. spare time school physical education and sports can have as well, under certain conditions, better options than compulsory school physical education. Thanks to the smaller number of attendants in this education process we can pay more attention to individual interests not applicable in compulsory school physical education.

\section{Materials and methods}

The goal of the research was to study the attitudes of primary school pupils towards physical education and movement activities, to find out the difference between boys' and girls' attitudes, between rural and urban schools and between pupils who attend and do not attend sports groups. In accordance with the research results, literary sources available and their own pedagogical practice the authors assumed that the boys would take more positive attitudes towards physical and movement activities than the girls, that the pupils attending sports groups would take more positive attitudes than pupils not attending any sports group and also pupils visiting rural schools would take more positive attitudes than urban school pupils.

There were 256 pupils participating in the research carried out in the 2014-2015 school year, the research specimen composed of 124 boys and 132 girls from eight primary schools in the Detva and Zvolen regions.

A questionnaire according to Sivák et al., (2000) was used to find out the specific declarative attitude of pupils towards activities - physical education and sports activities. The research was carried out within the scientific VEGA project 1/0606/15.

\section{Results and discussion}

The research was focused on discovering the attitudes of pupils towards physical education and sports activities, so therefore the authors were mainly interested in the relationship of pupils towards physical and sports activities, their frequency and favourite sport activities among them.

In the past others were concerned with the problem of primary school pupils' attitudes towards physical education, e.g. Chromík et al. (1993), Antala and Dorošová (1996), Görner and Starší (2001), Bartík (2005, 2006, 2007), Vladovičová and Novotná (2005), Mesiarik (2013) and Palička (2013). The most interesting results were presented by Görner and Starší (2001), who were performing their research on $6^{\text {th }}$ and the $8^{\text {th }}$ grades pupils in selected primary schools in the Central Slovak Region. The authors listed above found out that the positive attitude towards school physical education and sports predominate among pupils of $6^{\text {th }}$ and the $8^{\text {th }}$ grades in those selected primary schools. Besides the great work of gym teachers, the authors placed the credit for the positive opinions about school physical education and sports on the fact that sports became a significant social phenomenon particularly through media such as TV. 


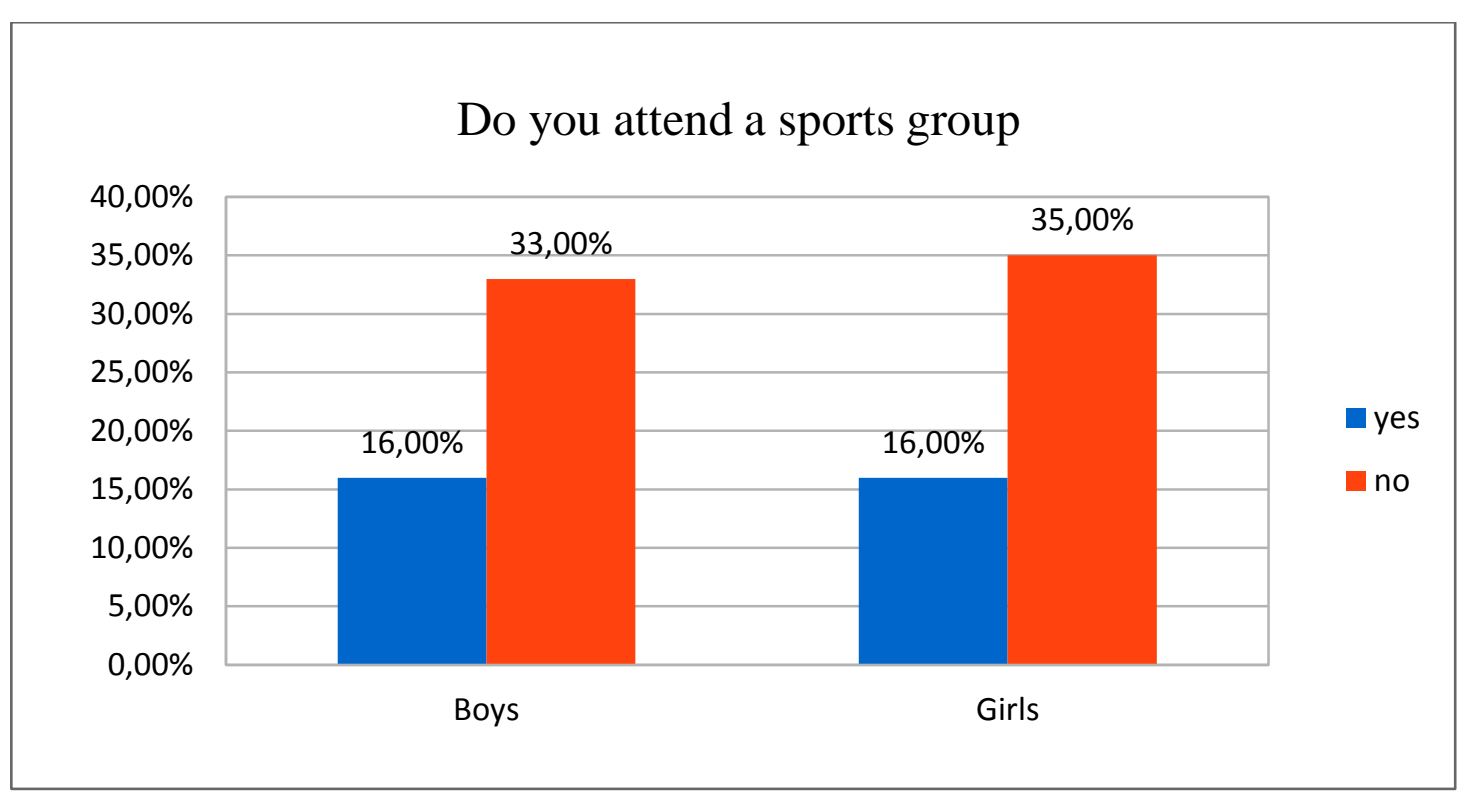

Figure 1. Do you attend a sports group

In Figure 1 we can see how many pupils of the specimen attend, or more precisely do not attend a sports group. It is clear that the interest in sports activities is on the same level between the boys and the girls, also seeing that more pupils do not attend a sports group. Interest school physical education and sports are very close to recreational physical education and sports, the application of this activity by youth also explored by many authors, such as Hrčka and Drdácka (1992), Smith (1994), Hrčka (1997), Liba (2002, 2003), Hrčka, Michal and Bartík (2004) along with Blahutková, Rehulka and Dvořáková (2005). They mainly emphasised the social and health significance of the movement and sports activities but also the preventive effect against different drug addictions.

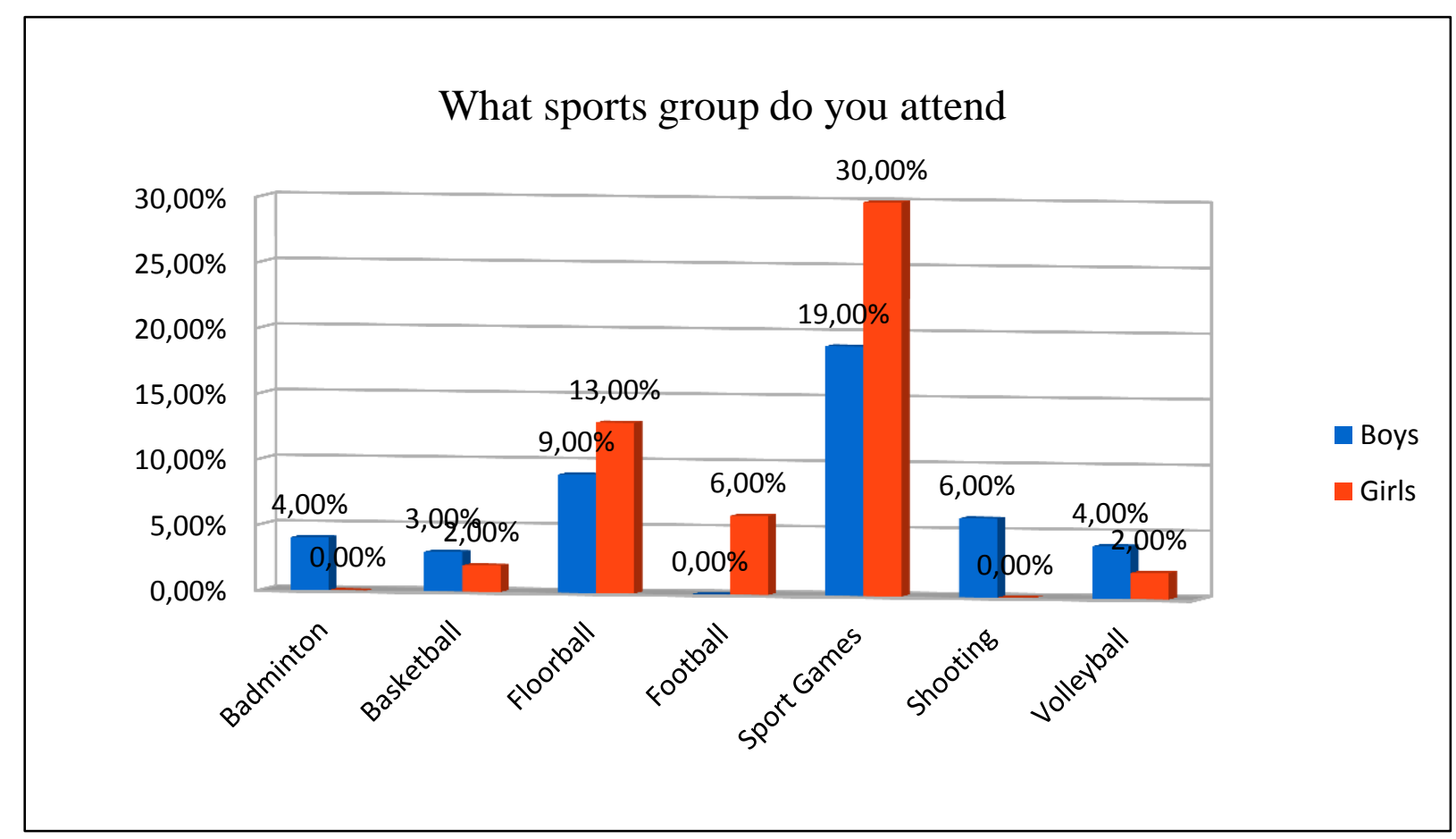

Figure 2. What sports group do you attend 
Apart from the frequency of attending sports groups the authors were also interested in which sports activities are the most attended. The most popular activities (Figure 2) were the sports games, which $19 \%$ of the girls and $30 \%$ of the boys were attending. Floorball is the second most popular activity; shooting, football and volleyball are preferred by $6 \%$ of pupils, basketball by $5 \%$ and badminton by $4 \%$.

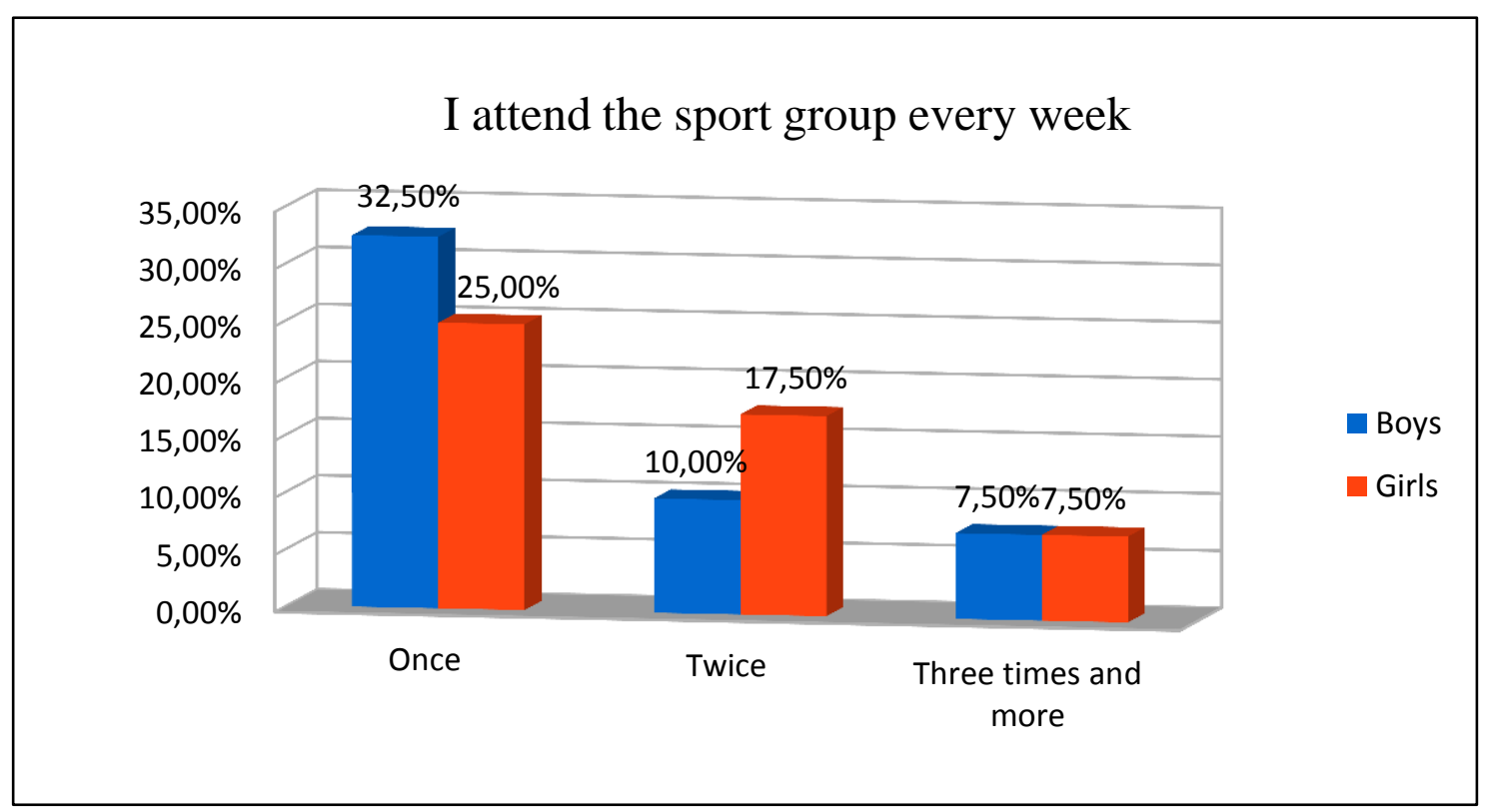

Figure 3. I attend a sports group every week

The results (Figure 3) show that today as a sedentary lifestyle is gaining ground and the informatization of the society is increasing, boys $(7.5 \%)$ and girls $(7.5 \%)$ in the $8^{\text {th }}$ grade of primary schools perform their chosen activity regularly three and more times weekly, which is according to the authors, not a positive relationship to a sports activity. Once a week $57.5 \%$ of the pupils attend a sports group and twice a week $27.5 \%$.

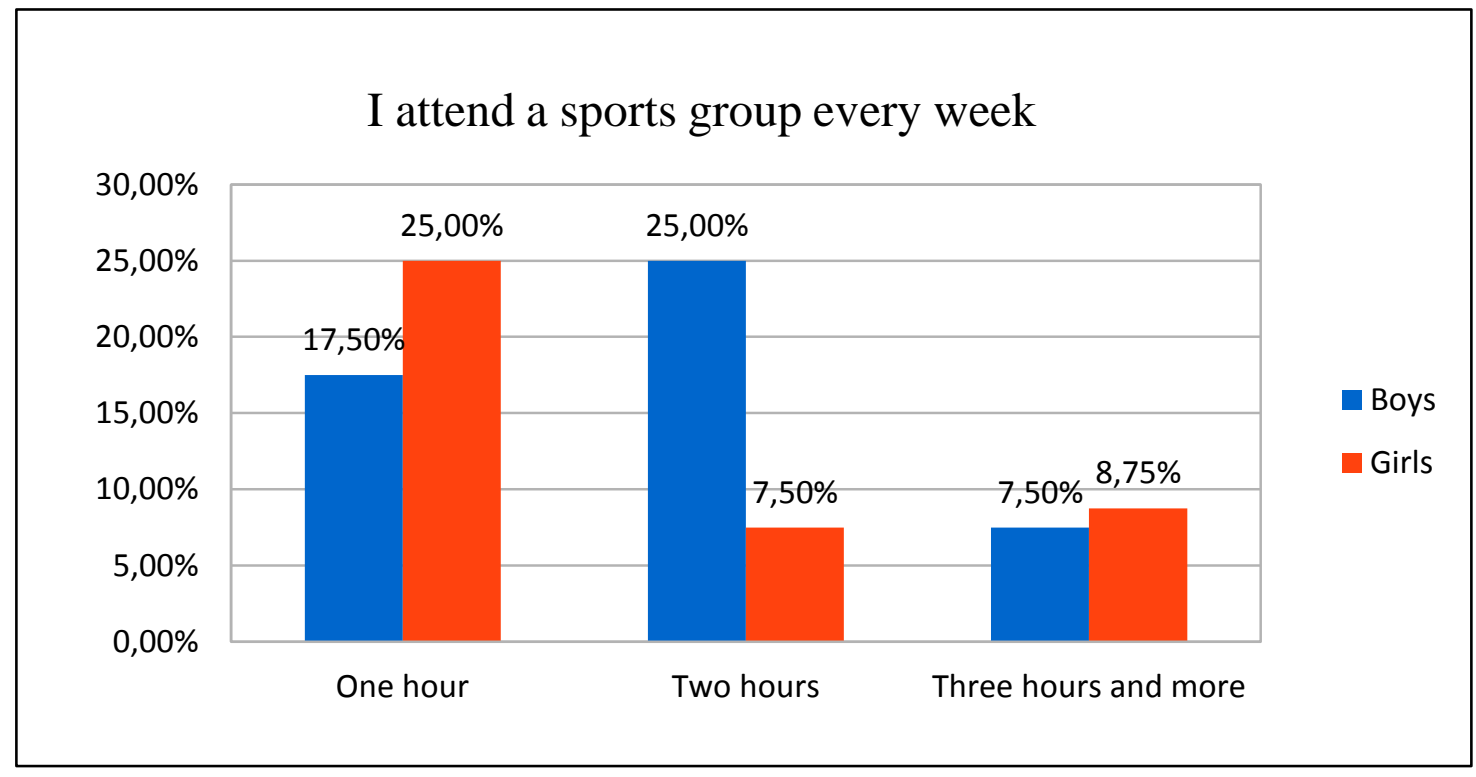

Figure 4. I attend a sports group every week

The authors were also interested in the number of hours the pupils spend on sports activity (Figure 4) within the sports group. The chart shows that $16.23 \%$ of the respondents spend three 
and more hours on the activity, $42.5 \%$ of the pupils saying they spend one hour weekly on the activity and $32.5 \%$ spend two hours every week on a sports activity within a sports group.

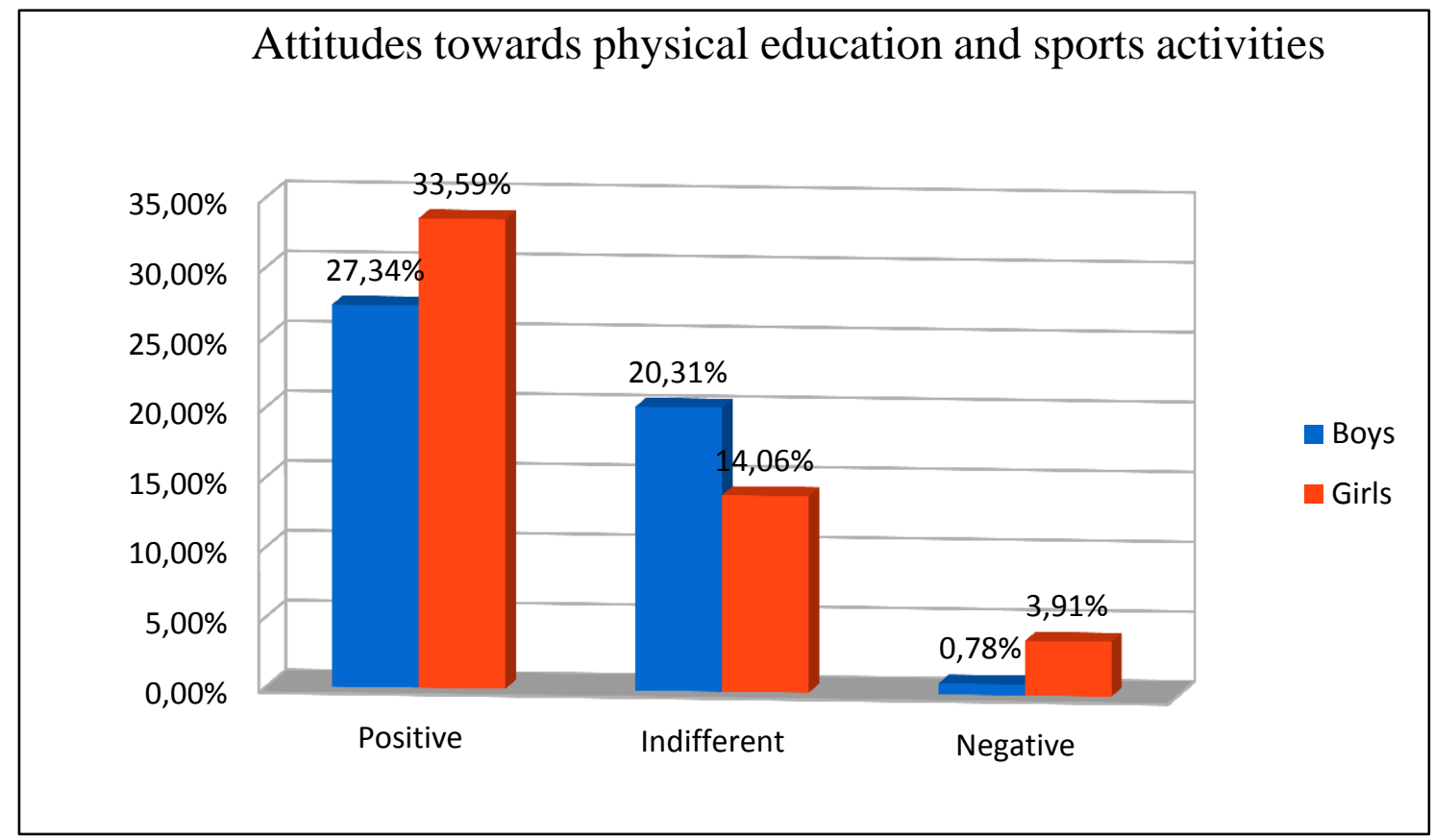

Figure 5. Attitudes towards physical education and sports activities

The results show (Figure 5) that $60.93 \%$ of pupils take a positive attitude towards physical and sports activities. Indifferent attitudes predominate in $34.37 \%$ of pupils and $4.69 \%$ of the respondents took a negative attitude. The assumption of the positive attitudes predominating in boys as opposed to girls was not confirmed in this research. The research on the subject of an attitude study towards school physical education and sports among the $6^{\text {th }}$ and the $8^{\text {th }}$ grades in the selected primary schools in the Central Slovak Region was carried out by Görner and Starší (2001). They observed a positive attitude towards school physical education and sports by both boys and girls.

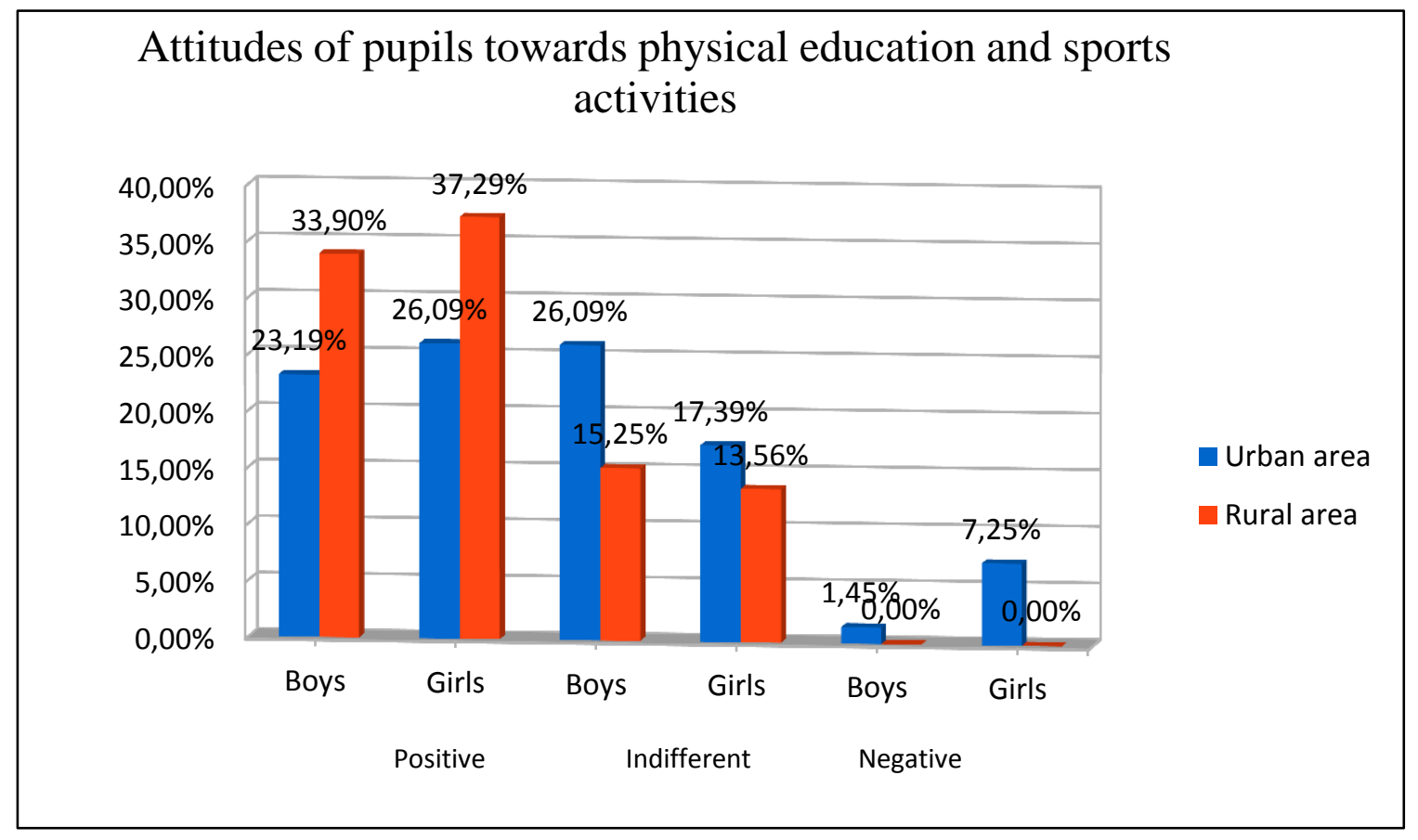


Figure 6. Attitudes of pupils towards physical education and sports activities

The results (Figure 6) show that among the boys (33.9 \%) and the girls as well (37.29 \%) attending a rural school there predominated positive attitudes towards physical and sports activities as opposed to boys (23.19 \%) and girls (26.09 \%) attending urban primary schools. Therefore the assumption made about the more positive attitudes of pupils attending rural primary schools as opposed to pupils attending urban schools was confirmed. We can also see the negative attitude that predominated in urban schools in $1.4 \%$ of boys and $7.25 \%$ of girls.

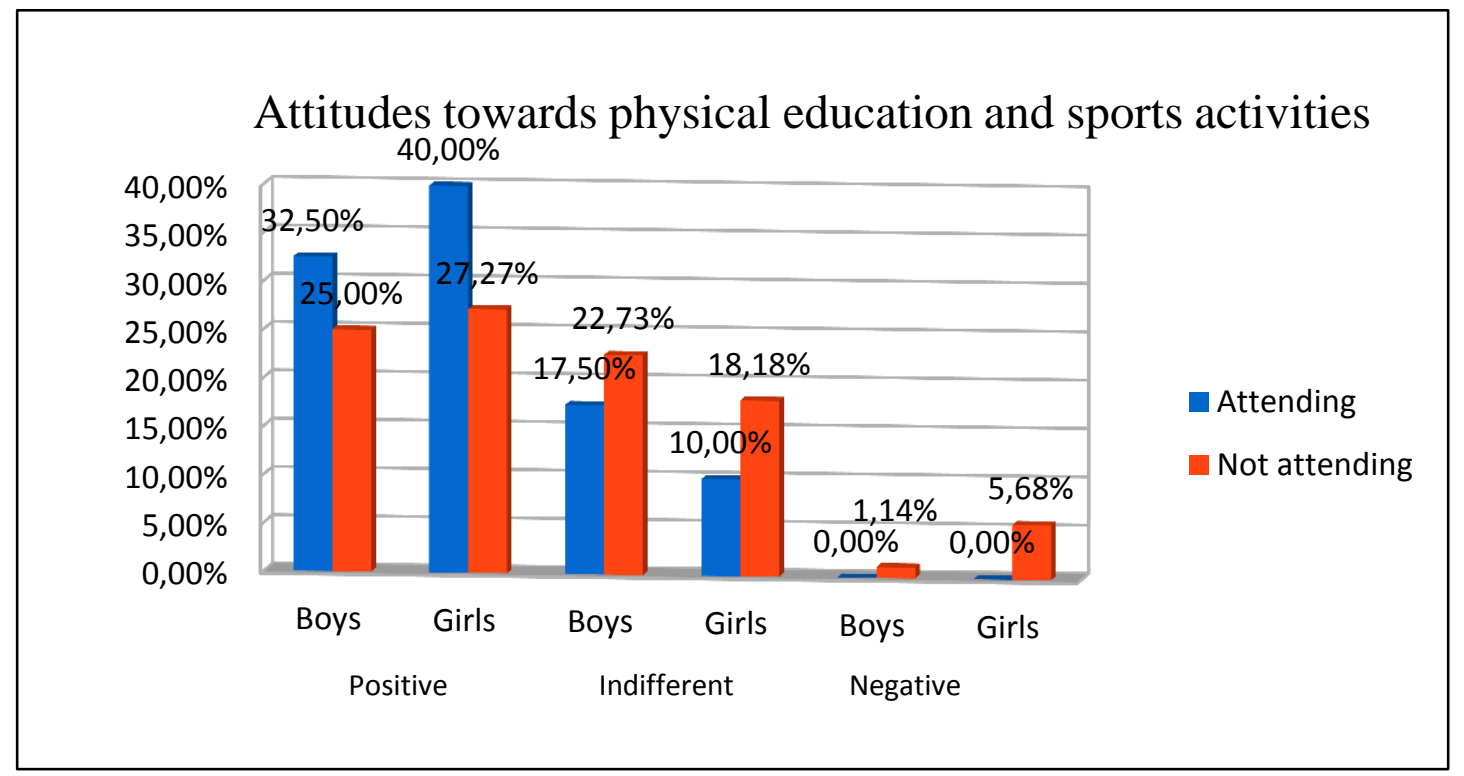

Figure 7. Attitudes of pupils attending/not attending a sports group

Finally the authors were interested in the difference of attitudes towards physical and sports activities among pupils who are and are not attending a sports group. The authors assumed that the attitudes of the pupils attending a sports group would be more positive than of the pupils not attending any sports group and this assumption was confirmed. The research results show (Figure 7 ) that $32.5 \%$ of boys and $40 \%$ of girls attending a sports group took a positive attitude as opposed to $25 \%$ of boys and $27.27 \%$ of girls not attending any sport group.

\section{Conclusion}

The research made in the primary schools in the Detva and Zvolen regions demonstrated primary school pupils' attitudes towards physical education and sports activities. The research findings did not confirm the more positive attitudes of the boys towards physical education and sports activities than the girls. In accordance to the findings we are able to state that pupils attending a sports group took a more positive attitude than pupils not attending any sports group; also that pupils attending rural schools took a more positive attitudes than urban school pupils.

Movement activity has a universal effect on people, with a great biological and humanistic effect on their life attitudes, work production, actual efficiency, eating habits, behaviour and selfimage (Labudová, 2002). School physical education has a great impact on the biological development of an individual and also on one's healthy lifestyle. One of the main functions of school physical education is to teach the pupils the most adequate way of developing their movement skills and abilities as well as a way of actively spending their free time along with extracurricular physical education.

For the practice requirement the authors recommend an active cooperation among the school, parents and sports groups with the goal of improving pupils' attitudes towards school physical education, regular movement and sports activities mainly among $8^{\text {th }}$ grade pupils in primary schools.

\section{References:}

1. ANTALA, B. - DOROŠOVÁ, S. 1996. Postoje žiakov pohybovo podpriemerných 
a pohybovo nadpriemerných ku školskej telesnej výchove. In Telesná výchova a šport, roč. 6, 1996, č. 4. ISSN 1335-2245, s. 8 - 10.

2. $\quad$ BARTÍK, P. 2005. Postoje žiakov 2. stupřa základnej školy k telesnej výchove. In Acta uvniversitatis Natthaei Belii, Zborník vedeckovýskumných prác, č. 9. Banská bystrica: UMB, 2005. ISBN 80-8083-161-0, s. 158-164.

3. BARTÍK, P. 2006. Postoje žiakov 1. stupňa Ž̌ k telesnej výchove a pohybovým aktivitám v regióne Čadca. In Sborník referátu z 6. medzinárodního vědeckého semináře „Efekty pohybového zatížení v edukačním prostředí tělesné výchovy a sportu“. Olomouc: FTK UP, 2006. ISBN 80-244-1366-3, s. 46

4. BARTÍK, P. 2007. Postoje žiakov 5. a 9. ročníkov na vybraných ZŠ k telesnej výchove. In Optimální pusobení tělesné záteže a výživy. Sborník příspevku ze XVI. Rožníku interdisciplinárni konference s medzinárodní účastí. Hradec Králové: PF UHK, 2007. ISBN 97880-7041-513-9, s. $210-216$.

5. BARTÍK, P. - KUBIŠ J. 2013. Záujem žiakov základných škôl o volnočasové pohybové aktivity v regióne mesta Detva, Banská Bystrica: UMB FHV, 2013. ISSN 1337-7310, In Exercitatio Corporis - Motus - Salus, s. 76

6. FRÖMEL, K. - NOVOSAD, J. - SVOZIL, Z. et al. 1999. Pohybová aktivita a športové záujmy mládeže. Olomouc: Univerzita Palackého, 1999. 141 s. ISBN 80-7067-945-X.

7. GÖRNER, K. 1998 Turistické aktivity volného času - činitele pozitívneho formovania mravných postojov. Vychovávatel': Časopis pedagógov, roč. 41, 1998. s. 18-20 ISSN 0139-6919.

8. GÖRNER, K. - STARŠÍ, J. 2001. Postoje, vedomosti a názory žiakov II. stupňa Ž́ na telesnú výchovu. Banská Bystrica: UMB, Fakulta humanitných vied, 2001, 162 s. ISBN 808055.565-6.

9. HENDL, J. 2004. Přehled statistických metod zpracování dat. Praha: Portál, 2004. 583 s., ISBN 80-7178-820-1.

10. CHROMÍK, M. et al. 1993. Didaktika telesnej výchovy. Bratislava: Univerzita Komenského Bratislava, 1993. 200 s. ISBN 80-224-0349-6.

11. KUBIŠ, J. 2015. Interest of Elementary School Pupils in Physical Activities and Recreational Sport in the Region Detva. Košice: UPJS, 2015, 208 s. ISBN 978-83-7455-442-8

12. MESIARIK, P. 2013. Postoje žiakov 2. stupňa základných škôl k telesnej a športovej výchove v kontexte školských vzdelávacích programov. Banská Bystrica: UMB FHV, 2013. $196 \mathrm{~s}$.

13. PALIČKA, M. 2013. Školský vzdelávací program a jeho vplyv na zmenu postojov žiakov základnej školy k telesnej a športovej výchove. Banská Bystrica: UMB FHV, 2013. 163 s.

14. SIVÂK, J. et al. 2000. Vzdelávací štandard z telesnej výchovy pre 2. stupeň základných škôl. Bratislava: MŠ SR, 2000. $31 \mathrm{~s}$.

15. VLADOVIČOVÁ, N. - NOVOTNÁ, N. 2005. Športové záujmy rómskych žiakov 1. stupňa základnej školy. In Acta universitatis Matthiae Belli, Zborník vedeckovýskumných prác, č. 9. Banská Bystrica: PF UMB, 2005, ISBN 80-8083-161-0, s. 173 - 179.

\title{
УДК 37
}

\section{Отношение младших школьников к физическому воспитанию и спорту}

\author{
${ }^{1}$ Павол Бартик \\ ${ }_{2}$ Жан Кубис
}

\footnotetext{
1-2 Университет Матея Бэла, Словакия

97401 г. Банска Быстрица, ул. Таёвскего, 40

${ }^{1}$ Доктор педагогических наук, $\mathrm{PhD}$, профессор

E-mail:pavol.bartik@umb.sk

${ }^{2}$ Магистр педагогических наук

E-mail: janesumb@gmail.com
} 
Аннотация. Одну из важнейших ролей в организации физического воспитания является формирование положительного отношения к спортивной деятельности и спорту среди учащихся. Положительное восприятие к спорту может сыграть важную роль в вопросе формирования здорового образа жизни ребенка. Поэтому авторы данной статьи решили выяснить, каково отношение учащихся начальных классов к физической культуре и спортивным мероприятиям в регионах Детва и Зволен. Авторы представляют отношение к физической культуре и спорту, а также спортивным мероприятиям школьников 8-го класса начальной школы школьников в регионах Детва и Зволен, а также их частоты. Авторы обсуждают вопросы, какие из внешкольных или в свободное от основной деятельности время мероприятий, являются наиболее популярными. Согласно результатам, представленных в исследовании, видно, что ученики имеют положительно относятся к занятиям физической культурой и спортом. Спортивные игры являются одними из самых любимых в группе предпочтений.

Ключевые слова: отношение, физическое воспитание, спортивные мероприятия, свободное от основной деятельности время. 